\title{
Bio-potential of Aqueous Extract of Verbesina encelioides, Moringa oleifera, Cassia fistula against Meloidogyne incognita
}

Pareek Apexa, Gaur Arvind, Lodha Payal

10.18805/IJARe.A-5836

\begin{abstract}
Background: The Meloidogyne incognita is the most destructive pathogen and causes loss of yield of various economically important plants of various families. It is polyphagous in behaviour and has a high reproductive rate, these parameters are a hurdle in management of it. Various chemicals are used to control nematode worldwide that are very expensive and highly toxic to the environment and human beings. For ecologically safe method, three plants i.e. Verbesina encelioides, Moringa oleifera, Cassia fistula and their various parts such as leaf, stem and flower's cold aqueous extracts were tried in vitro to test their nematicidal activity.

Methods: Cold aqueous extracts $(10 \% \mathrm{w} / \mathrm{v})$ of each plant material were prepared by mixing $10 \mathrm{~g}$ of each plant material in $100 \mathrm{ml}$ of distilled water and kept aside for 48 hours. To estimate inhibition of egg hatching and mortality rate of second stage juveniles of Meloidogyne incognita, eggs and juveniles were exposed for 24,48 and 72 hours in different concentrations (20 ppm to 200 ppm) of plant extracts.

Result: All three tested plant extracts showed promising nematicidal activity against Meloidogyne incognita and the leaf extract of Moringa oleifera prevents the hatching of eggs. Inhibition of larval hatching from egg and nematode mortality rate were strongly influenced by concentration of extract, plant species and duration of exposure.
\end{abstract}

Key words: Chemical, Hatching, Management, Meloidogyne incognita, Mortality, Nematicidal.

\section{INTRODUCTION}

The production of most vegetables crops is affected by soil borne diseases that are caused by soil pathogens such as Rhizoctonia spp., Fusarium spp., Phythium spp., Phytophthora spp. and Meloidogyne spp. (Panth et al., 2020). Above all mentioned soil pathogens, Meloidogyne spp is highly devastating pathogen to a wide range of plants and causing US \$100 billion annual loss in yield globally (Oka et al. 2000; Kiewnick et al. 2006). Significant yield losses in various crops such as Tomatoes, Okra, Cotton have been observed as a result of soil inhabiting Meloidogyne incognita by Du et al. 2020; Baheti and Bhati, 2017; Memoona et al. 2014 respectively

To control root knot nematode, various chemical such as Methyl Bromide (as soil fumigant), Fenamiphos, Ethoprop, Oxamyl, Aldicarb were used but after the implementation of Montreal Protocol, the application of Methyl Bromide has been banned in majority of countries (US-EPA, 2020) and Aldicarb has been banned for environmental concern (FDACS, 2021). In recent years, the use of nematicides is not considered a useful mean to control pathogens as they being highly toxic cause deleterious effect on human health and environment and are costly too affecting the economy of farmers (Nico et al. 2004; Huang et al. 2014).

Hence, in order to overcome the drawbacks of nematicides and to safeguard the environment, maintaining ecological balance, managing root knot nematode (here after RKN) population, fulfilling farmers requirement, biological control has emerged as an alternative method, which is cost effective and eco-friendly (Collange et al. 2011). A new approach such as the use of plants and their derivatives (phytochemicals) as nematicidal agents against broad range
Department of Botany, University of Rajasthan, Jaipur-302004, Rajasthan, India.

Corresponding Author: Pareek Apexa, Department of Botany, University of Rajasthan, Jaipur-302 004, Rajasthan, India.

Email: pareekapeksha34@gmail.com

How to cite this article: Apexa, P., Arvind, G., Payal, L. (2021). Bio-potential of Aqueous Extract of Verbesina encelioides, Moringa oleifera, Cassia fistula against Meloidogyne incognita. Indian Journal of Agricultural Research. DOI: 10.18805/IJARe.A-5836.

Submitted: 03-06-2021 Accepted: 18-08-2021 Online: 09-09-2021

phytoparasitic nematodes is developing recently. (Sardari et al. 2015; Kepenekci et al. 2016). Insunza et al. (2001) evaluated aqueous extract of thirty plants as nematicidal agents against Xiphinema americanum sensu lato and Elbadri et al. (2008) screened the methanol and hexane extracts of twenty seven plants against Meloidogyne incognita. The main objective of this study was to evaluation of nematicidal activity of aqueous extracts of various plant parts (like leaf, stem, root and flowers) of Verbesina encelioides (Cav.) Benth. and Hook. f. ex A. Gray, Moringa oleifera Lam. and Cassia fistula L. against Meloidogyne incognita in vitro.

\section{MATERIALS AND METHODS Collection of plant materials}

All three selected plants were collected from campus of University of Rajasthan in month of March to May (flowering season) and identified in the herbarium of Department of Botany. Plant materials were washed with tap water to 
remove dust and debris and then finally washed by distilled water. The Leaves, stems and flowers of each plants were separated and air dried by placing them on blotting paper in dark. Roots of Verbesina encelioides plants were also dried. After drying, each plant material was grinded to obtain fine powder at room temparature.

\section{Preparation of aqueous extract of plants}

Cold aqueous extracts $(10 \% \mathrm{w} / \mathrm{v})$ of each plant material were prepared by mixing $10 \mathrm{~g}$ of each plant material in $100 \mathrm{ml}$ of distilled water and kept aside for 48 hours. All the extracts were filtrated and each filtrate was evaporated using a hot plate at a temperature $50^{\circ} \mathrm{C}$. The concentrated solution each plant was stored in refrigerator at $4^{\circ} \mathrm{C}$ as stock solution. At the time of experiment 20-200 ppm concentration from stock solutions was prepared by dissolving filtrate into distilled water. Distilled water was used as control.

\section{Preparation of inoculum}

To establish pure culture of Meloidogyne incognita, a single mass was removed from infected plant and surface sterilized with $0.5 \% \mathrm{NaOCl}$ subsequently rinsed with double distilled water for five times. Then after single egg mass was inoculated into a pot containing okra plant in sterilized soil and kept at room temperature for 2-3 months to maintain pure culture. Pure egg masses were teased out from infected plant of okra manually under the microscope and cleaned with distilled water.

\section{In-vitro evaluation of nematicidal property of plant extracts}

Effect of each plant extracts on hatchability of egg was determined by suspending 5 mature egg masses in each plant extracts of different concentration in cavity blocks. For each plant material three replicates were prepared and all cavity blocks were kept at room temperature. These blocks were observed after 24,48 and $72 \mathrm{hr}$ and the readings were recorded.

Percentage mortality of each plant aqueous extract were determined by placing newly hatched $30 \mathrm{~J}_{2}$ larva in 20-200 ppm concentration of each plant extracts and observed after 24, 48 and 72 hours. Analysis of variance (ANOVA) was used to analysis variationnnnn and data analysis in the experiment and means were separated from

Table 1: Effect of different concentration of plant extracts on egg hatchability in the RKN, Meloidogyne incognita.

\begin{tabular}{|c|c|c|c|c|c|c|c|c|c|c|c|c|c|}
\hline \multirow{2}{*}{ Name of plant } & \multirow{2}{*}{$\begin{array}{l}\text { Parts } \\
\text { used }\end{array}$} & \multirow{2}{*}{$\begin{array}{l}\text { Exposure } \\
\text { time in } \mathrm{hr}\end{array}$} & \multicolumn{11}{|c|}{ Egg hatchability at different concentration (ppm) } \\
\hline & & & Control & 20 & 40 & 60 & 80 & 100 & 120 & 140 & 160 & 180 & 200 \\
\hline \multirow[t]{12}{*}{ Verbesina encelioides } & \multirow[t]{3}{*}{ Leaf } & 24 & 20 & 32 & 29 & 26 & 22 & 19 & 15 & 13 & 09 & 06 & 01 \\
\hline & & 48 & 27 & 26 & 21 & 18 & 14 & 11 & 08 & 07 & 04 & 00 & 00 \\
\hline & & 72 & 36 & 23 & 17 & 12 & 10 & 09 & 06 & 03 & 00 & 00 & 00 \\
\hline & \multirow[t]{3}{*}{ Stem } & 24 & 20 & 34 & 28 & 23 & 20 & 17 & 14 & 10 & 09 & 04 & 00 \\
\hline & & 48 & 27 & 30 & 25 & 21 & 17 & 13 & 13 & 09 & 07 & 03 & 00 \\
\hline & & 72 & 36 & 25 & 20 & 18 & 16 & 14 & 11 & 08 & 07 & 02 & 00 \\
\hline & \multirow[t]{3}{*}{ Root } & 24 & 20 & 20 & 16 & 14 & 11 & 09 & 07 & 07 & 05 & 04 & 01 \\
\hline & & 48 & 27 & 18 & 13 & 12 & 10 & 08 & 07 & 04 & 03 & 01 & 00 \\
\hline & & 72 & 36 & 10 & 06 & 06 & 04 & 02 & 01 & 00 & 00 & 00 & 00 \\
\hline & \multirow[t]{3}{*}{ Flower } & 24 & 20 & 35 & 30 & 28 & 25 & 21 & 19 & 15 & 13 & 08 & 05 \\
\hline & & 48 & 27 & 27 & 25 & 22 & 20 & 16 & 12 & 09 & 06 & 05 & 01 \\
\hline & & 72 & 36 & 21 & 20 & 17 & 15 & 11 & 08 & 05 & 03 & 01 & 00 \\
\hline \multirow[t]{9}{*}{ Moringa oleifera } & \multirow[t]{3}{*}{ Leaf } & 24 & 20 & 16 & 15 & 13 & 10 & 08 & 05 & 04 & 02 & 01 & 00 \\
\hline & & 48 & 27 & 10 & 09 & 08 & 06 & 03 & 01 & 00 & 00 & 00 & 00 \\
\hline & & 72 & 36 & 02 & 01 & 00 & 00 & 00 & 00 & 00 & 00 & 00 & 00 \\
\hline & \multirow[t]{3}{*}{ Stem } & 24 & 20 & 36 & 32 & 27 & 23 & 23 & 19 & 17 & 15 & 12 & 11 \\
\hline & & 48 & 27 & 24 & 22 & 18 & 16 & 13 & 10 & 09 & 09 & 05 & 03 \\
\hline & & 72 & 36 & 19 & 17 & 14 & 11 & 07 & 07 & 05 & 04 & 03 & 02 \\
\hline & \multirow[t]{3}{*}{ Flower } & 24 & 20 & 31 & 29 & 23 & 21 & 18 & 15 & 12 & 11 & 09 & 05 \\
\hline & & 48 & 27 & 28 & 26 & 23 & 20 & 17 & 14 & 11 & 09 & 06 & 03 \\
\hline & & 72 & 36 & 24 & 21 & 20 & 17 & 15 & 13 & 10 & 07 & 04 & 00 \\
\hline \multirow[t]{9}{*}{ Cassia fistula } & \multirow[t]{3}{*}{ Leaf } & 24 & 20 & 39 & 39 & 37 & 36 & 33 & 25 & 20 & 17 & 13 & 07 \\
\hline & & 48 & 27 & 33 & 30 & 34 & 32 & 27 & 22 & 17 & 13 & 09 & 04 \\
\hline & & 72 & 36 & 27 & 25 & 22 & 18 & 18 & 15 & 15 & 12 & 11 & 03 \\
\hline & \multirow[t]{3}{*}{ Stem } & 24 & 20 & 30 & 30 & 26 & 23 & 22 & 17 & 14 & 13 & 10 & 08 \\
\hline & & 48 & 27 & 26 & 25 & 21 & 21 & 18 & 15 & 12 & 10 & 07 & 05 \\
\hline & & 72 & 36 & 18 & 17 & 15 & 13 & 10 & 09 & 07 & 05 & 04 & 04 \\
\hline & \multirow[t]{3}{*}{ Flower } & 24 & 20 & 32 & 30 & 28 & 22 & 19 & 15 & 11 & 09 & 09 & 07 \\
\hline & & 48 & 27 & 34 & 30 & 26 & 21 & 17 & 13 & 10 & 08 & 08 & 05 \\
\hline & & 72 & 36 & 29 & 26 & 24 & 18 & 15 & 11 & 08 & 06 & 04 & 03 \\
\hline
\end{tabular}




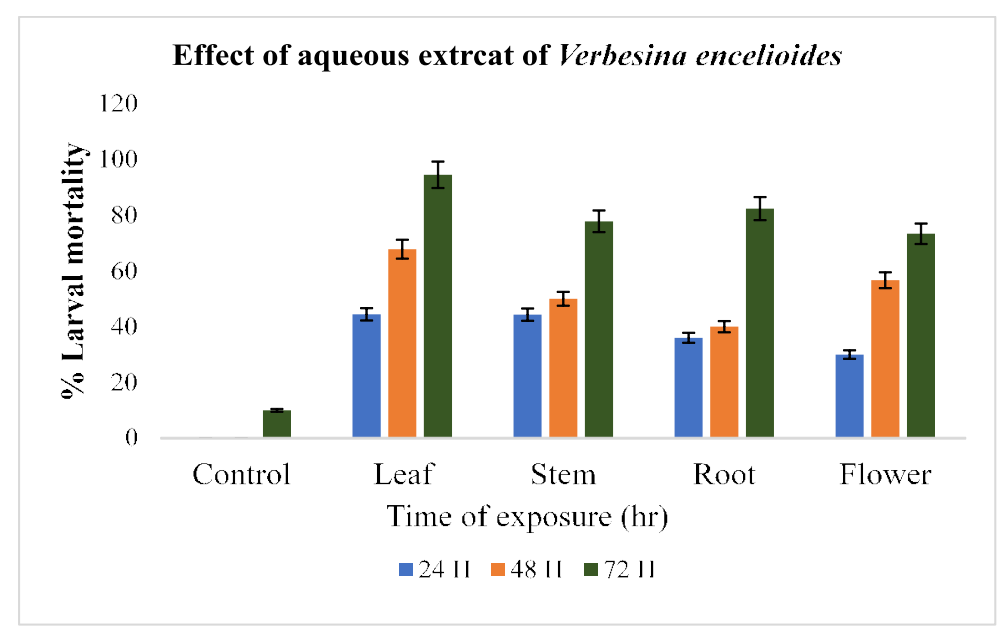

A
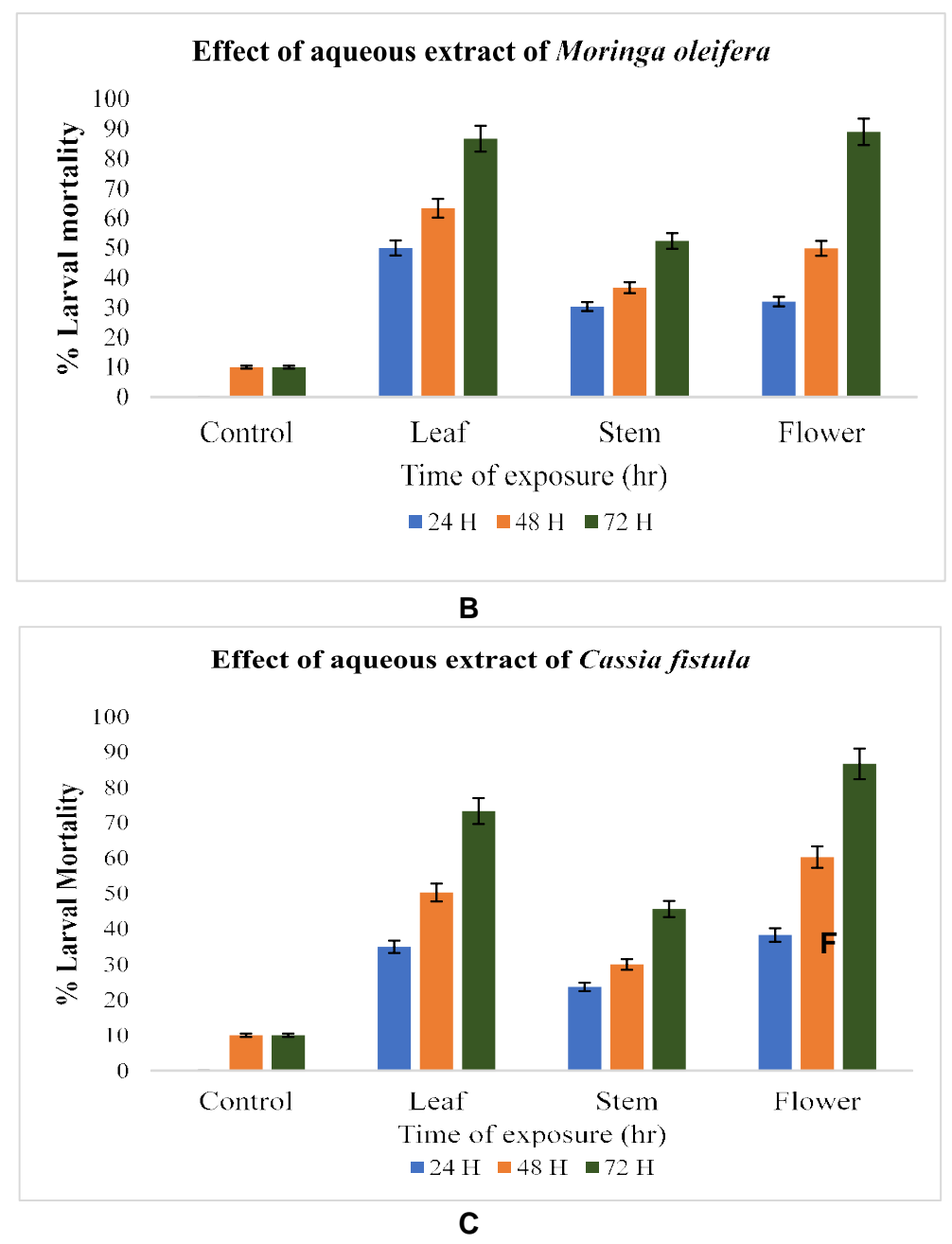

Fig 1: Effect of aqueous extract of (A) Verbesina encelioides (B) Moringa oleifera (C) Cassia fistula on mortality of larva. 
Duncan multiple test range. Lethal concentration (hereafter LC) 30,50 and 90 were also determined by Probit analysis. Distilled water was used as control.

The hatchability was determined by following formula $=$

$$
\text { hatched larvae } / 5
$$

The percentage mortality was calculated by following formula $=$

$$
\frac{\text { Total dead larvae }}{\text { Total larvae }} \times 100
$$

\section{RESULTS AND DISCUSSION}

\section{Hatchability}

Egg hatchability decreased with increase in extract concentration and time of exposure. All tested plants showed effective nematicidal properties. The root and leaf extract of Verbesina encelioides was more lethal to Meloidogyne incognita than flower and stem extract. Among all extracts the most effective extract was leaf extract of Moringa oleifera.
It showed $95-97 \%$ inhibition of hatching egg after 72 hours $(\mathrm{P}<0.005)$. Effect of different concentration of plant extracts on egg hatchability in the RKN, Meloidogyne incognita is mentioned in Table 1.

\section{Mortality}

Percentage of larval mortality increases with concentration of extracts and exposure time. Results of Verbesina encelioides, Moringa oleifera and Cassia fistula are presented in Fig 1 A,B,C respectively.

Highest percentage larvae mortality $(94.47 \pm 0.44)$ was shown in leaf extract of Verbesina encelioides. Stem extracts of each plant showed lowest mortality rate. Percentage mortality of stem extract of Verbesina encelioides, Moringa oleifera and Cassia fistula were $77.77 \pm 0.77,52.35 \pm 0.09$ and $45.67 \pm 0.77$, respectively.

Flower extracts also showed prominent nematicidal activity on $\mathrm{J}_{2}$ juveniles. Percentage mortality of flower extract of Verbesina encelioides, Moringa oleifera and Cassia fistula were $73.33 \pm 0.49,88.96 \pm 0.33$ and $86.67 \pm 0.17$, respectively.

\begin{tabular}{|c|c|c|c|c|c|c|c|c|c|c|c|c|c|}
\hline \multirow{2}{*}{ Name of plant } & \multirow{2}{*}{$\begin{array}{l}\text { Parts } \\
\text { used }\end{array}$} & \multirow{2}{*}{$\begin{array}{l}\text { Exposure } \\
\text { time in } \mathrm{hr}\end{array}$} & \multicolumn{11}{|c|}{$\%$ of larval mortality at different conc. (in ppm) of plant extracts } \\
\hline & & & Control & 20 & 40 & 60 & 80 & 100 & 120 & 140 & 160 & 180 & 200 \\
\hline \multirow[t]{12}{*}{ Verbesina encelioides } & Leaf & 24 & 0.00 & 0.00 & 0.00 & 2.20 & 6.67 & 14.43 & 18.87 & 23.33 & 27.93 & 33.33 & 44.43 \\
\hline & & 48 & 10.00 & 0.00 & 4.44 & 21.11 & 25.56 & 30.00 & 32.22 & 40.00 & 47.78 & 57.78 & 67.78 \\
\hline & & 72 & 10.00 & 10.00 & 12.20 & 22.23 & 28.13 & 31.90 & 40.00 & 50.00 & 67.77 & 75.57 & 94.47 \\
\hline & Stem & 24 & 0.00 & 0.00 & 0.00 & 0.00 & 11.10 & 22.23 & 28.90 & 31.10 & 33.33 & 38.87 & 44.43 \\
\hline & & 48 & 10.00 & 0.00 & 0.00 & 12.20 & 14.43 & 18.90 & 28.90 & 30.00 & 37.77 & 40.00 & 50.00 \\
\hline & & 72 & 10.00 & 0.00 & 0.00 & 11.10 & 22.23 & 33.33 & 40.00 & 50.00 & 55.57 & 66.67 & 77.77 \\
\hline & Root & 24 & 0.00 & 0.00 & 2.00 & 3.67 & 7.33 & 10.67 & 15.67 & 19.67 & 18.67 & 24.33 & 36.00 \\
\hline & & 48 & 10.00 & 1.00 & 3.33 & 6.67 & 8.33 & 11.67 & 18.66 & 20.00 & 23.33 & 26.67 & 40.00 \\
\hline & & 72 & 10.00 & 3.33 & 6.67 & 16.66 & 20.00 & 26.33 & 33.66 & 53.33 & 60.32 & 75.67 & 82.33 \\
\hline & Flower & 24 & 0.00 & 0.00 & 0.00 & 0.00 & 3.33 & 13.33 & 16.67 & 20.00 & 23.67 & 26.33 & 30.00 \\
\hline & & 48 & 10.00 & 0.00 & 3.33 & 6.67 & 16.67 & 20.00 & 26.67 & 36.67 & 43.33 & 53.33 & 56.67 \\
\hline & & 72 & 10.00 & 0.00 & 3.33 & 8.33 & 22.67 & 24.57 & 33.33 & 40.00 & 53.33 & 60.00 & 73.33 \\
\hline \multirow[t]{9}{*}{ Moringa oleifera } & Leaf & 24 & 0.00 & 0.00 & 0.00 & 3.33 & 8.89 & 15.56 & 15.56 & 21.11 & 32.22 & 41.11 & 50.00 \\
\hline & & 48 & 10.00 & 0.00 & 0.00 & 6.67 & 10.00 & 20.00 & 23.33 & 36.67 & 46.67 & 50.00 & 63.33 \\
\hline & & 72 & 10.00 & 3.33 & 6.67 & 16.67 & 23.33 & 36.67 & 53.33 & 60.00 & 66.67 & 73.33 & 86.67 \\
\hline & Stem & 24 & 0.00 & 0.00 & 0.67 & 3.33 & 6.67 & 9.33 & 13.67 & 19.33 & 22.00 & 27.00 & 30.33 \\
\hline & & 48 & 10.00 & 3.33 & 6.67 & 8.00 & 13.33 & 15.00 & 20.00 & 23.67 & 26.67 & 33.67 & 36.67 \\
\hline & & 72 & 10.00 & 6.67 & 11.33 & 16.67 & 23.36 & 27.00 & 32.58 & 37.56 & 42.33 & 49.45 & 52.35 \\
\hline & Flower & 24 & 0.00 & 0.00 & 2.33 & 3.00 & 6.33 & 8.67 & 14.00 & 18.00 & 23.67 & 27.00 & 32.00 \\
\hline & & 48 & 10.00 & 3.22 & 6.67 & 9.00 & 13.33 & 15.00 & 21.33 & 26.67 & 33.33 & 40.67 & 49.86 \\
\hline & & 72 & 10.00 & 6.67 & 11.37 & 19.38 & 23.67 & 33.35 & 42.57 & 53.67 & 68.33 & 74.58 & 88.96 \\
\hline \multirow[t]{9}{*}{ Cassia fistula } & Leaf & 24 & 0.00 & 0.00 & 0.00 & 0.33 & 2.67 & 5.33 & 10.33 & 16.33 & 22.33 & 28.67 & 35.00 \\
\hline & & 48 & 10.00 & 1.00 & 3.00 & 9.33 & 9.33 & 12.67 & 17.33 & 23.67 & 33.00 & 42.33 & 50.33 \\
\hline & & 72 & 10.00 & 6.67 & 9.33 & 16.67 & 16.67 & 20.00 & 24.00 & 33.33 & 46.67 & 53.67 & 73.33 \\
\hline & Stem & 24 & 0.00 & 0.00 & 0.00 & 0.00 & 3.33 & 6.00 & 10.00 & 13.33 & 16.67 & 20.00 & 23.67 \\
\hline & & 48 & 10.00 & 0.00 & 0.00 & 3.33 & 6.67 & 6.67 & 13.33 & 16.67 & 23.33 & 26.67 & 30.00 \\
\hline & & 72 & 10.00 & 0.00 & 0.00 & 10.00 & 13.33 & 15.00 & 23.33 & 26.67 & 33.33 & 37.67 & 45.67 \\
\hline & Flower & 24 & 0.00 & 0.00 & 0.00 & 1.00 & 2.33 & 4.67 & 8.33 & 9.67 & 18.33 & 25.67 & 38.33 \\
\hline & & 48 & 10.00 & 0.00 & 2.67 & 4.67 & 10.33 & 18.33 & 26.33 & 36.67 & 43.67 & 51.33 & 60.33 \\
\hline & & 72 & 10.00 & 3.33 & 10.00 & 23.33 & 35.67 & 43.67 & 56.67 & 66.67 & 75.00 & 86.67 & 86.67 \\
\hline
\end{tabular}

Table 2: Effect of different concentration of plant extracts on larval mortality of the RKN, Meloidogyne incognita. 
In-vitro effect of different concentration of all plant extracts with incubation time on Second stage juvenile of Meloidogyne incognita is represented in Table 2 and LC with 30,50 and 90 was determined by Probit analysis and also mentioned in Table 3.

Root system of most of the vegetables crops is affected by obligate endoparasite RKN, Meloidogyne incognita and cause of knot like formation on roots. To control RKN various methods such as chemical (known as nematicides) physical, biological and resistant cultivars are applied. Among all of methods, application of chemical as fumigants, sprayer, liquid is very effective and gives quick results to the farmers but most of the chemicals were banned due to their toxic and carcinogenic nature not only to human being but also for animals and also harmful to environment (Wachira et al. 2009; Dubey et al. 2011).

Present study is related to above mentioned approach. It was observed that all three tested plants showed nematicidal activity against Meloidogyne incognita in vitro and confirmed that plants have nematicidal properties. The nematicidal properties of a plant extract such inhibition of egg hatch and mortality to $\mathrm{J}_{2}$ larva was depend upon time of exposure and concentration of extract. Similar result was obtained by Elbadari et al. 2008; Wiranto et al. 2009; Khan et al. 2019.

Aqueous leaves extract of each selected plant species viz Jatropha pandurifolia, Polyalthia longifolia, Wedelia chinensis, Nerium indicum, Duranta repens, Cassia fistula (Asif et al. 2014) and Amygdalus scoparia, Arctium lappa (Farzaneh et al. 2019) showed $99-100 \%$ mortality rate and had nematicidal activity after 48 hours of exposure. The leaf extract of Moringa oleifera was the highly active in decreasing egg hatchability. The leaf extract of Verbesina encelioides was the highly active in increasing mortality of juveniles. In previous study, leaves extract of Neem (Azadirachta indica) showed $100 \%$ mortality rate against RKN in vitro condition (Oka et al. 2007), 95-99\% mortality of juveniles of RKN was observed in leaves extract of six plants after $72 \mathrm{~h}$ of exposure (Elbadri et al. 2008).

Flower and stem extract of tested plants also affected the juveniles of Meloidogyne incognita. Verbesina encelioides, Moringa oleifera, Cassia fistula have potential to control Root Knot Nematode, Meloidogyne incognita. Highest mortality was recorded in leaf extract of Verbesina

Table 3: Lethal concentration of all tested plant extracts.

\begin{tabular}{|c|c|c|c|c|c|}
\hline Name of plant & Part used & Exposure time in hours & LC 30 & LC 50 & LC 90 \\
\hline \multirow[t]{12}{*}{ Verbesina encelioides } & Leaf & 24 & 190.55 & 151.36 & 323.59 \\
\hline & & 48 & 107.15 & 38.04 & 263.63 \\
\hline & & 72 & 66.37 & 107.40 & 363.08 \\
\hline & Stem & 24 & 152.05 & 184.50 & 299.23 \\
\hline & & 48 & 135.52 & 169.04 & 290.40 \\
\hline & & 72 & 105.93 & 138.36 & 221.82 \\
\hline & Root & 24 & 165.20 & 225.42 & 484.17 \\
\hline & & 48 & 247.74 & 363.08 & 1671.09 \\
\hline & & 72 & 83.56 & 129.12 & 378.44 \\
\hline & Flower & 24 & 176.60 & 217.77 & 366.44 \\
\hline & & 48 & 121.90 & 159.22 & 305.49 \\
\hline & & 72 & 110.92 & 141.91 & 261.22 \\
\hline \multirow[t]{9}{*}{ Moringa oleifera } & Leaf & 24 & 147.57 & 183.65 & 316.96 \\
\hline & & 48 & 130.32 & 160.32 & 266.69 \\
\hline & & 72 & 75.68 & 113.76 & 309.03 \\
\hline & Stem & 24 & 168.27 & 227.51 & 478.63 \\
\hline & & 48 & 181.97 & 396.28 & 2691.53 \\
\hline & & 72 & 101.16 & 216.27 & 1406.05 \\
\hline & Flower & 24 & 167.49 & 228.03 & 487.53 \\
\hline & & 48 & 147.91 & 291.07 & 1534.62 \\
\hline & & 72 & 70.47 & 112.46 & 356.45 \\
\hline \multirow[t]{9}{*}{ Cassia fistula } & Leaf & 24 & 183.23 & 226.46 & 381.94 \\
\hline & & 48 & 153.46 & 262.42 & 979.49 \\
\hline & & 72 & 101.62 & 194.98 & 974.99 \\
\hline & Stem & 24 & 197.24 & 246.60 & 428.55 \\
\hline & & 48 & 169.43 & 215.28 & 389.05 \\
\hline & & 72 & 142.23 & 178.24 & 309.74 \\
\hline & Flower & 24 & 183.23 & 232.81 & 419.76 \\
\hline & & 48 & 124.45 & 161.81 & 307.61 \\
\hline & & 72 & 65.46 & 96.38 & 249.46 \\
\hline
\end{tabular}


encelioides and Moringa oleifera and also in root extract of Verbesina encelioides. These plants can be used for management of Meloidogyne incognita.

\section{CONCLUSION}

Extracts and dried material of above mentioned plants can be used to control root knot nematode, Meloidogyne incognita and a good alternative of chemical nematicides. However, further research on their mechanism of action and formulation of a chemical that is toxic to root knot nematode are required for the best result.

\section{REFERENCES}

Asif, M., Parihar, K., Rehman, B., Ashraf Ganai, M., Usman, A. and Siddiqui, M.A. (2014). Bio-efficacy of some leaf extracts on the inhibition of egg hatching and mortality of Meloidogyne incognita. Archives of Phytopathology and Plant Protection. 47: 1015. DOI:10.1080/03235408.2013.829626.

Baheti, B.L. and Bhati, S. (2017). Estimation of losses caused by root-knot nematode, Meloidogyne incognita in varied soil conditions on okra (Abelmoschus esculentus L.). Current Nematology. 28: 201-207.

Collange, B., Navarrete, M., Peyre, G., Mateille, T. and Tchamitchian, M. (2011). Root knot nematode (Meloidogyne) management in vegetable crop production: the challenge of an agronomic system analysis. Crop Protection. 30: 1251-1262.

Du, B., Xu, Y., Dong, H., Li, Y. and Wang, J. (2020). Phanerochaete chrysosporium strain B-22, a nematophagous fungus parasitizing Meloidogyne incognita. PLoS ONE. 15(1): e0216688. https://doi.org/10.1371/journal.pone.0216688.

Dubey, N.K., Shukla, R., Kumar, A., Singh, P. and Prakash, B. (2011). Global Scenario on the Application of Natural Products in Integrated pest Management. Natural Products in Plant Pest Management (Dubey, N.K., CABI, Oxford shire, UK.), 20.

Elbadri, G., Lee, D., Park, J., Yu, H. and Choo, H. (2008). Evaluation of various plant extracts for their nematicidal efficacies against juveniles of Meloidogyne incognita. Journal of Asia-Pacific Entomology. 11: 99-102.

Farzaneh, R., Habiballah, C. and Mohammad, A. (2019). Evaluation of burdock and mountain almond leaf extracts against Meloidogyne javanica on tomato. Archives of Phytopathology and Plant Protection. 52: 1035-1047.

FDACS (2021, April 21), FDACS Issues Denial of Aldicarb Pesticide Usage Application in Florida. (Press release). https://www. fdacs.gov/News-Events/Press-Releases/2021-PressReleases/FDACS-Issues-Denial-of-Aldicarb-PesticideUsage-Application-in-Florida

Huang, W.K., Sun, J.H., Cui, J.K., Wang, G.F., Kong, L.A., Peng, $\mathrm{H}$., et al. (2014). Efficacy evaluation of fungus Syncephalastrum racemosum and nematicide avermectin against the root- knot nematode Meloidogyne incognita on cucumber. PLoS One. 9(2): e89717. https://doi.org/10.1371/journal.pone. 0089717.

Insunza, V., Aballay, E., Macaya, J. (2001). In vitro nematicidal activity of aqueous plant extracts on chilean populations of Xiphinema americanum sensu lato. Nematropica. 31: 47-54.

Kepenekci, I., Erdogus, D., Erdogan, P. (2016). Effects of some plant extracts on root-knot nematodes in vitro and in vivo conditions. Turkish Journal of Entomology. 40: 3. DOI: 10. 16970/TED.84688.

Khan, F., Asif, M., Khan, A., Tariq, M., Ansari, T., Shariq, M. and Siddiqui, M.A. (2019). Evaluation of the nematicidal potential of some botanicals against root-knot nematode, Meloidogyne incognita infected carrot: in vitro and greenhouse study. Current Plant Biology. 20: 100-115.

Kiewnick, S., Sikor, R.A. (2006). Biological control of the root-knot nematode Meloidogyne incognita by Paecilomyces lilacinus strain 251. Biological Control. 38(2): 179-187.

Memoona, I., Khola, R., Sania, A., Sobia, Z., Fakiha, A., Maria, K., Alvina, G.K. and Abdul, M.K. (2014). Preventing Potential Diseases of Crop Plants under the Impact of a Changing Environment. In: Emerging Technologies and Management of Crop Stress Tolerance, [P. Ahmad, S. Rasool (Eds.)], Academic Press. https://doi.org/10.1016/B978-0-12800875-1.00009-0, (pp 193-214).

Nico, A.l., Jiménez-Díaz R.M., Castillo, P. (2004). Control of rootknot nematodes by composted agro-industrial wastes in potting mixtures. Crop Protection. 23(7): 581-587.

Oka, Y., Koltai, H., Bar-Eyal, M., Mor, M., Sharon, E., Chet, I., Spiegel, Y. (2000). New strategies for the control of plant-parasitic nematodes. Pest Management Science. 56: 983-988.

Oka, Y., Tkachi, N., Shuker, S., Yerumiyahu, U. (2007). Enhanced nematicidal activity of organic and inorganic ammoniareleasing amendments by Azadirachta indica extracts. Journal of Nematology. 39: 9-16.

Panth, M., Hassler, S.C., Baysal-Gurel, F. (2020). Methods for management of soil borne diseases in crop production. Agriculture. 10(1): 16 ; https://doi.org/10.3390/agriculture 10010016.

Sardari, A.A., Hojat Jalali, A.A., Bahraminejad, S. and Safaee, D. (2015). Effect of plant extracts on the mortality of rootknot nematodes $\mathrm{J}_{2}$, Meloidogyne javanica. Archives of Phytopathology and Plant Protection. 48: 365-375.

Wachira, P.M., Kimenju, J.W., Okoth, S.A. and Miley, R.K., (2009). Stimulation of nematode destroying fungi by organic amendments applied in management of plant parasitic nematode. Asian Journal of Plant Science. 8: 153-159.

Wiratno, Taniwiryono, D., Berg, H., Riksen J.,Rietjens I., Djiwanti, S., Kammenga, J. and Murk, A. (2009). Nematicidal activity of plant extracts against the root-knot nematode, Meloidogyne incognita. The Open Natural Products Journal. 2: 77-85. 